\title{
Low Levels of Apolipoprotein A Are Not Contributors to the Low Lecithin-Cholesterol Acyl Transferase Activity in Premature Newborn Infants
}

\author{
SANIA AMR, PARVEEN CHOWDHRY, PAUL HAMOSH, AND MARGIT HAMOSH \\ Departments of Pediatrics and Physiology and Biophysics, Georgetown University Medical Center, \\ Washington, D.C. 20007
}

\begin{abstract}
Umbilical cord sera were obtained from three groups of newborn infants; group I $((n=8)$ and group II $(n=12)$ weighed less than $1500 \mathrm{~g}$ and between 1500 and $2500 \mathrm{~g}$, respectively. Group III $(n=16)$ was full term and weighed more than $2500 \mathrm{~g}$. Lecithin-cholesterol acyl transferase activities, determined as the rates of esterification of $\left[{ }^{3} \mathrm{H}\right]$ cholesterol, were $0.13 \pm 0.01,0.17 \pm 0.01$, and 0.26 $\pm 0.01($ mean \pm SEM) $\mathrm{nmol} / \mathrm{h} / \mathrm{ml}$ for groups I, II, and III, respectively. The adult value $(n=8)$ was $0.96 \pm 0.01$ $\mathrm{nmol} / \mathrm{h} / \mathrm{ml}$. The respective apolipoprotein $\mathrm{A}_{1}\left(\right.$ apo- $\left.\mathrm{A}_{1}\right)$ levels were $52 \pm 6,59 \pm 4$, and $67 \pm 4$ (mean $\pm S E M) \mathrm{mg} /$ dl. Serum level of apo-A in adults was $137 \pm 6 \mathrm{mg} / \mathrm{dl}$. Plasma high-density lipoprotein cholesterol levels increased with gestational age. However, in newborn infants, high-density lipoprotein apo-lipoprotein B, total cholesterol, and triglyceride levels, were significantly lower than in adults. These data indicate that serum levels of lecithincholesterol acyl transferase activity significantly $(p<0.01)$ increase whereas the levels of apo-A $A_{1}$ do not significantly change with the gestational age. Also, in full-term newborns, lecithin-cholesterol acyl transferase activity is only $27 \%$, whereas apo- $A_{1}$ levels are $49 \%$ of adult values. Therefore, lower levels of apo- $A_{1}$ do not account for the significantly lower activity of lecithin-cholesterol acyl transferase in preterm as compared to full-term newborn infants. (Pediatr Res 24: 191-193, 1988)
\end{abstract}

\section{Abbreviations}

LCAT, lecithin-cholesterol acyl transferase

Apo-A, apolipoprotein $A_{1}$

HDL, high-density lipoprotein

Apo-B, apolipoprotein B

LCAT is an enzyme that converts plasma lecithin and unesterified cholesterol to lysolecithin and cholesteryl ester, and therefore, it plays a key role in the metabolism of phospholipids $(1,2)$. The latter, as one of the components of fat emulsions, is commonly administered to low birth weight premature infants, who are maintained on total parenteral nutrition. In these new-

Received January 21, 1988; accepted March 29, 1988.

Correspondence and requests for reprints Dr. Sania Amr, Basic Science Building, Room 207, Georgetown University Medical Center, 3800 Reservoir Road, N.W. Washington, D.C. 20007-2197.

Supported by NIH Grant HD-15631 and by Georgetown University Biomedical Research grant RR 05360. borns, Intralipid overload leads to phospholipid accumulation and hyperlipemia (3-8) that could be due to low LCAT activity. Indeed, LCAT activity was found to be lower at birth than in adults $(9-12)$. Therefore, attempts to understand the mechanism(s) involved in lipid clearing and particularly the regulatory factors of LCAT activity, have been made $(10,13-16)$. Several investigators focused their attention on apo- $A_{1}$, which is the essential cofactor of LCAT activity and the principal apolipoprotein of plasma HDL $(1,2)$. Serum apo-A, levels, like LCAT activities, were found to be lower at birth than in adults $(10,13-$ 16). However, if the reduced enzyme activity is due to low levels of its cofactor remains unclear.

In our study, we examined the developmental patterns of apo$A_{1}$ levels and LCAT activities in preterm newborn infants. Umbilical cord sera, obtained from two groups of premature and one group of full-term newborns, were analyzed and compared to sera obtained from adults. We found no direct correlation between apo- $\mathrm{A}_{1}$ levels and LCAT activities.

\section{MATERIALS AND METHODS}

Three groups of infants were studied (Table 1). The experimental protocol was approved by the committee for research on human subjects of Georgetown University Hospital. Group I consisted of eight premature babies with birth weight less than $1500 \mathrm{~g}$. In this group there was one case of sepsis and another case of HIV infection. Hyaline membrane disease was the common diagnosis in the six other newborns. Twelve newborns, weighing between 1500 and $2500 \mathrm{~g}$, constituted group II; five infants were diagnosed as having transient respiratory distress. In both groups (I and II), and within each group, there was no significant difference between the infants with respect to the parameters studied. Group III was composed of 16 healthy fullterm infants weighing more than $2500 \mathrm{~g}$. A control group, consisting of eight healthy adults (four males, four females), was also studied.

Blood samples were taken from the umbilical cords of newborns and kept at $4^{\circ} \mathrm{C}$ overnight. After centrifugation, the sera were stored at $-20^{\circ} \mathrm{C}$. The blood samples, taken from adults, were similarly treated.

LCAT activity was determined as the rate of esterification of $\left[{ }^{3} \mathrm{H}\right]$ cholesterol, according to the technique of Albers et al. (17). Apo- $A_{1}$ and Apo-B were measured by radioimmunoassay, using kits purchased from Ventrex Laboratories (Portland, ME). Serum triglycerides and total and HDL cholesterol levels were determined enzymatically according to the manufacturer's protocol (Sigma Chemical Co., St. Louis, MO).

For statistical analysis, Student's $t$ test and analysis of variance were used. 
Table 1. Clinical parameters of different groups of newborn infants*

\begin{tabular}{|c|c|c|c|}
\hline Group & $n$ & $\begin{array}{l}\text { Birth wt } \\
\text { (g) }\end{array}$ & $\begin{array}{c}\text { Gestational age } \\
\text { (wk) }\end{array}$ \\
\hline I & $\begin{array}{c}8 \\
\text { (3 males, } 5 \text { females) }\end{array}$ & $\begin{array}{l}943 \pm 58 \\
(790-1195)\end{array}$ & $\begin{array}{l}28.7 \pm 1.3 \\
(25-36)\end{array}$ \\
\hline II & $\begin{array}{c}12 \\
\text { (7 males, } 5 \text { females) }\end{array}$ & $\begin{array}{l}1987 \pm 78 \\
(1590-2340)\end{array}$ & $\begin{array}{l}33.4 \pm 0.5 \\
(31-36)\end{array}$ \\
\hline III & \begin{tabular}{l}
\multicolumn{3}{c}{16} \\
$(6$ males, 10 fe- \\
males $)$
\end{tabular} & $\begin{array}{l}3283 \pm 94 \\
(2610-3960)\end{array}$ & $\begin{array}{l}39.7 \pm 0.2 \\
(38-41)\end{array}$ \\
\hline
\end{tabular}

* The data are expressed as the means \pm SEM (range).

\section{RESULTS}

LCAT activity was measured as the rate of esterification of cholesterol $/ \mathrm{h} / \mathrm{ml}$ of serum. The results showed that the enzyme activity increased significantly with the gestational age (Fig. 1), but remained, in full-term infants, much lower than in adults $(27 \%)$. In these newborns, apo- $A_{1}$ levels, which were only $49 \%$ of those observed in adults, did not differ significantly from the levels measured in preterm infants (Fig. 2). Therefore, the increment in LCAT activity was not parallel to the change in apo- $A_{1}$ levels. As shown in Figure 3, there was no direct correlation between LCAT activity and apo- $\mathrm{A}_{1}$ levels in newborn infants.

To further investigate the lipid profiles of these groups, we simultaneously determined the serum levels of Apo-B, triglycerides, and cholesterol. Total and HDL cholesterol varied with the gestational age (Table 2). Total cholesterol was higher in infants with very low birth weight than in full-term babies. In contrast, HDL cholesterol increased significantly with gestational age. In full-term infants, although plasma HDL cholesterol constituted $45 \%$ of total cholesterol levels, the amount remained lower than in adults, where HDL cholesterol levels were only $19 \%$ of total cholesterol. Apo-B and triglyceride levels were lower in newborn infants than in adults (Table 2).

\section{DISCUSSION}

In our study, we determined the levels of LCAT activity and apo- $\mathrm{A}_{\mathrm{I}}$ in umbilical cord sera of preterm and full-term newborn infants. We found that the enzyme activity significantly increased, whereas apo- $\mathrm{A}_{1}$ levels did not vary with the gestational age. Also, in full-term newborns, LCAT activity was only $27 \%$, whereas apo- $A_{1}$ levels were $49 \%$ of adult values. These data strongly support the lack of correlation between the levels of LCAT activity and apo- $\mathrm{A}_{1}$ concentration in newborn infants. Previous studies have shown that cord plasma LCAT activity and apo- $A_{1}$ levels in full-term infants are much lower than those in adults $(10,13-16)$. Inasmuch as apo- $A_{1}$ is the essential cofactor in the activation of LCAT it was hypothesized that the reduced levels of the former might account for the low levels of the latter (2). Our data, showing the patterns of both parameters during gestation, argue against this hypothesis. We found that plasma HDL cholesterol levels increased with the gestational age in a manner parallel to the increase in LCAT activity. Such an increase was earlier reported (18). Inasmuch as HDL are the substrate for LCAT, it is plausible that the low levels of the former could be responsible for the very low activity of the latter in premature infants. However, at term, LCAT activity was proportionally much lower than the levels of its substrate (HDL) in adults ( 27 and $73 \%$ of the adult values, respectively). Although it is possible that low concentration of apo- $A_{1}$ and/or HDL might contribute to the lower LCAT activity, it is unlikely that the lack of substrate and/or activator is the major factor. More likely is the possibility that low levels of the enzyme per se are responsible for low LCAT activity in newborn infants. Further

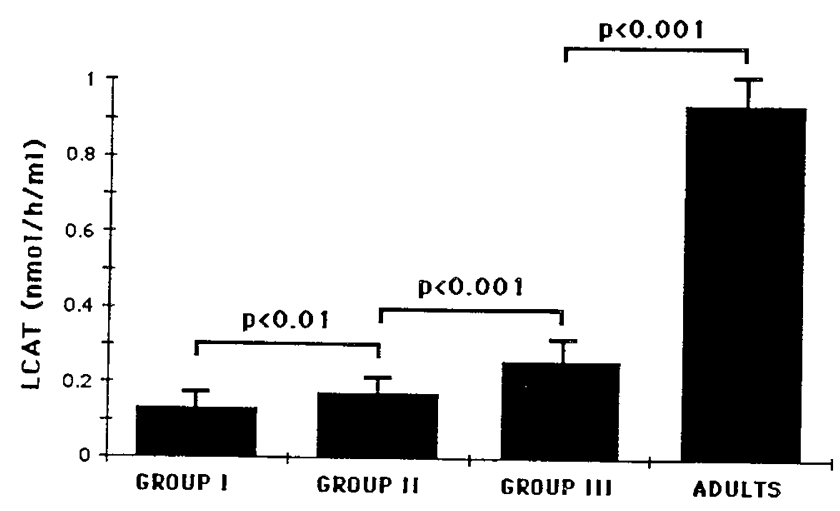

Fig. 1. LCAT activity in serum samples obtained from umbilical cords of newborn infants and from adults. The data represent the means $\pm 2 \mathrm{SD}$.

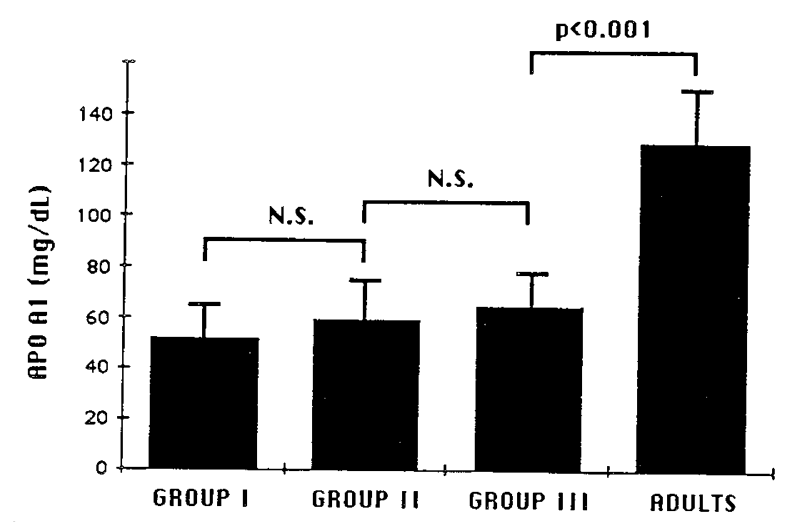

Fig. 2. Apo- $A_{1}$ levels in serum samples obtained from umbilical cords of newborn infants and from adults. The data represent the means \pm 2 $\mathrm{SD}$.

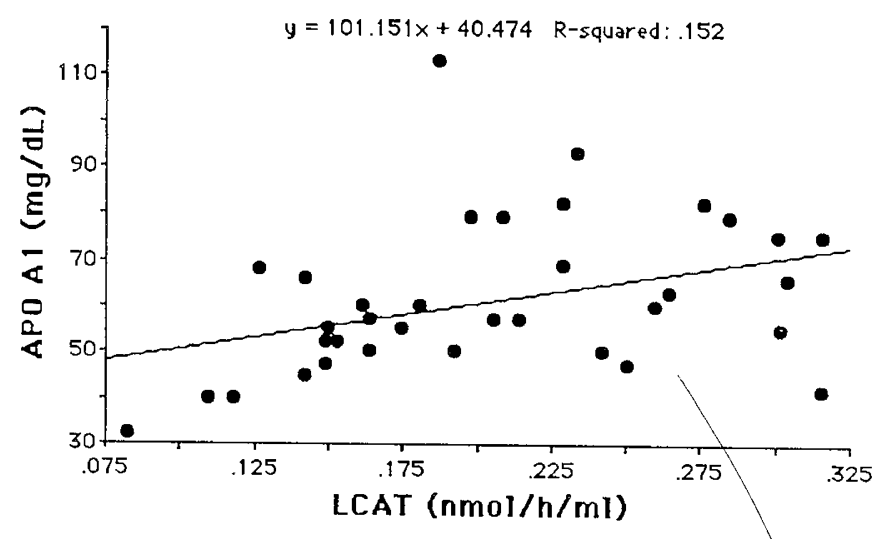

Fig. 3. Correlation between LCAT activity and apo- $\mathrm{A}_{1}$ levels in preterm and full-term newborn infants.

investigations aiming at the quantitative determination of LCAT concentration in addition to its activity, will be necessary to confirm this possibility.

The deficiency of LCAT is of clinical importance in newborns and particularly in very low birthweight infants, to whom administration of Intralipid is commonly used. Indeed, in adult humans (19) and in young rats (20) parenteral nutrition with Intralipid leads to decrease in LCAT activity and impairs the metabolism of exogenous lecithin present in Intralipid. Consequently, an increase not only in serum phospholipid and triglyceride, but also in cholesterol levels occurs $(3-8,21)$. The resulting hyperlipemia points to the importance of careful monitoring of 
Table 2. Serum levels of Apo-B, total and HDL cholesterol and triglycerides in newborn infants and adults*

\begin{tabular}{|c|c|c|c|c|}
\hline \multirow[b]{2}{*}{ Group } & \multicolumn{2}{|c|}{ Cholesterol } & \multirow[b]{2}{*}{ Apo-B } & \multirow[b]{2}{*}{ Triglycerides } \\
\hline & Total & $\mathrm{HDL}$ & & \\
\hline I & $75 \pm 12 \dagger$ & $11 \pm 1$ & $31 \pm 4$ & $60 \pm 12$ \\
\hline II & $\{51 \pm 4$ & $16 \pm 2\}+$ & $28 \pm 2\}+$ & $42 \pm 4$ \\
\hline III & $\int 55 \pm 3$ & $25 \pm 1$ & $22 \pm 1\}$ & $49 \pm 4$ \\
\hline Adults & $\{175 \pm 14$ & $34 \pm 2\}$ & $76 \pm 6\} \pm$ & $100 \pm 11\} \neq$ \\
\hline
\end{tabular}

* The data represent the means \pm SEM $(\mathrm{mg} / \mathrm{dl})$.

$\dagger p<0.05$.

$+p<0.001$.

preterm infants parenterally fed with Intralipid, with respect to their serum lipids and plasma LCAT and lipoprotein lipase and hepatic lipase activities. Therefore the dose and modality of administration of Intralipid will have to be established based on the basal levels of these parameters. Also, in some cases, a modification of the lipid emulsion, especially with respect to its lecithin content, might have to be considered.

Acknowledgments. The authors thank Mrs. Barbara RunnerAvery for her secretarial help.

\section{REFERENCES}

1. Glomset JA, Norum KR 1973 The metabolic role of lecithin: cholesterol acyltransferase. Perspectives from pathology. Adv Lipid Res 11:1-65

2. Dobiasova M 1983 Lecithin: cholesterol acyitransferase and the regulation of endogenous cholesterol transport. Adv Lipid Res 20:107-194

3. Berkow SE, Spear ML, Stahl GE, Gutman A, Polin RA, Pereira GR, Olivecrona T, Hamosh P, Hamosh M 1987 Total parenteral nutrition with Intralipid in premature infants receiving TPN: effect on plasma lipolytic enzymes, lipids, and glucose. J Pediatr Gastroenterol Nutr 6:581-588

4. Griffin E, Breckenridge WC, Kuksis A, Bryan MH, Angel A 1979 Appearance and characterization of lipoprotein-X during continuous Intralipid infusion in the neonate. J Clin Invest 64:1703-1712

5. Thompson GR, Jadhav A, Nava M, Gotto AM Jr 1976 Effects of intravenous phospholipids on low density lipoprotein turnover in man. Eur J Clin Invest 6:241-248

6. Taskinen MR, Tulikora I, Nikkila EA, Ehnholm C 1981 Effect of parenteral hyperalimentation on serum lipoproteins and on lipoprotein lipase activity of adipose tissue and skeletal muscle. Eur J Clin Invest 11:317-324

7. DeLeeu W, Kok K, DeVries IJ, Beganovic N 1985 Tolerance of intravenously administered lipid in newborns. Acta Pediatr Scand 74:52-56

8. Cooke RJ, Buis M, Zee P, Yeh YY 1985 Safflower oil emulsion administration during parenteral nutrition in the preterm infant. Effect on triglyceride and free fatty acid levels. J Pediatr Gastroenterol Nutr 4:804-807

9. Cisternas JR, Llanos A, Riquelme R, Caledon JM 1976 Plasma lecithin: cholesterol acyltransferase activity in newborn term infants. J Pediatr 89:323

10. Dobiasova M, Stozicky F, Kopecka J 1984 Lecithin-cholesterol acyltransferase in children in the early neonate period. Biol Neonate 45:165-168

11. Jain SK 1985 Prematurity and lecithin-cholesterol acyltransferase deficiency in newborn infants. Pediatr Res 19:58-60

12. Papadopoulos A, Hamosh M, Chowdhry P, Scanlon JW, Hamosh P 1988 Lecithin cholesterol acyl transferase in the newborn: low activity levels in preterm infants. J Pediatr (in press).

13. McConathy WJ, Lane DM 1980 Studies on the apolipoproteins and lipoproteins of cord serum. Pediatr Res 14:757-761

14. Stozicky F, Slaby P, Volenikova L 1982 The pattern of major serum apolipoproteins during the early neonatal period. Acta Pediatr Scand 71:239-24

15. Dolphin PJ, Breckenridge WC, Dolphin MA, Tan MH 1984 The lipoproteins of human umbilical cord blood apolipoprotein and lipid levels. Atherosclerosis $51: 109-122$

16. Lane DM, McConathy WJ 1986 Changes in the serum lipids and apolipoproteins in the first four weeks of life. Pediatr Res 20:332-337

17. Albers JJ, Chen CH, Lacko AG 1986 Isolation, characterization and assay of lecithin-cholesterol acyltransferase. Methods Enzymol 129:763-783

18. Ginsburg BE, Zetterstrom R 1977 High-density lipoprotein concentration in newborn infants. Acta Paediatr Scand 66:39-41

19. Untracht SH 1982 Intravascular metabolism of an artificial transporter of triacylglycerols. Alteration of serum lipoproteins resulting from total parenteral nutrition with Intralipid. Biochim Biophys Acta 711:176-192

20. Amr S, Hamosh P, Hamosh M 1988 Intralipid infusion decreases lecithincholesterol acyl transferase (LCAT) activity and increases cholesterol levels in young rats. Pediatr Res $23: 478 \mathrm{~A}$

21. Shennan AT, Bryan MH, Angel A 1977 The effect of gestational age on Intralipid tolerance in newborn infants. J Pediatr 91:134-137 